\title{
Mansikan mustalaikku säilyy pohjoisessa ilmastossa
}

Päivi Parikka ${ }^{1}$, Anne Lemmetty ${ }^{1}$, Gunn Mari Strømeng ${ }^{2}$, Thomas Sundelin ${ }^{3}$, Arne Stensvand ${ }^{2}$ ${ }^{1}$ MTT kasvintuotannon tutkimus, Jokioinen, Suomi, ${ }^{2}$ Bioforsk Plant Health and Plant Protection Division, Ås, Norja, ${ }^{3}$ Kööpenhaminan Yliopisto, Tanska

\section{TIIVISTELMÄ}

Mansikan mustalaikun aiheuttaja Colletotrichum acutatum on Keski-Euroopassa mansikan lisäksi tärkeä hedelmien, kuten omenan ja kirsikan pilaaja. Mansikan marjoihin kehittyvät tummat laikut pilaavat nopeasti satoa kosteassa ja lämpimässä. Tauti leviää helposti taimissa ja se kulkeutui tuontitaimien mukana mansikkaviljelmille Suomeenkin 2000-luvun alussa.

Pohjoismainen yhteistyö mustalaikun tutkimuksessa alkoi vuonna 2008 Suomessa, Norjassa ja Tanskassa erilaisissa ilmasto-oloissa. Mustalaikun aiheuttajan säilymistä seurattiin keinollisesti tartutetussa mansikan lehti-, rönsy- ja juurakkomassassa kolmen vuoden ajan suomalaisilla ja kahden vuoden ajan muilla koepaikoilla. Suomessa kokeet olivat MTT:n tutkimuspaikoilla Jokioisilla, Mikkelissä ja Sotkamossa, Norjassa Oslon lähellä Åsissa ja länsirannikolla Ullensvangissa sekä Tanskassa Kööpenhaminassa. Taudinaiheuttajan tartutuskyky testattiin kokeiden aikana vuosittain keväällä ja syksyllä. Koealueilta otetuilla näytteillä tartutettiin pyydyskasveja, joista määritettiin C. acutatum tartunta PCR-menetelmällä käyttäen lajispesifisiä alukkeita.

Colletotrichum acutatum voi säilyä Pohjoismaiden oloissa maassa kasvinjätteessä kaksi vuotta, jopa pitempään. Vain Tanskassa sieni säilyi tartutuskykyisenä heikommin, yhden talven yli. Maan kosteus ja lämpöolot vaikuttavat sienen säilymiseen, mikä näkyi Åsin ja Mikkelin tuloksissa. Sen sijaan Jokioisilla, Sotkamossa ja Ullensvangissa C. acutatum säilyi vähintään kaksi vuotta maassa tai maan pinnalla. Aikaisempien havaintojen mukaan taudinaiheuttaja säilyi rikkakasvien jätteessä vuoden verran. Tämä aines hajoaa nopeammin ja säilyminen on siinä vähäisempää kuin mansikan jätteessä. Pohjoisessa alhaiset lämpötilat lisäävät taudin säilymisaikaa ja maan jäätyminen hidastaa sen tuhoutumista kasvinjätteestä.

Kahden vuoden aikana koealueille kasvoi vesiheinää, rönsyleinikkiä, piharatamoa ja kurjenpolvea, joita testattaessa havaittiin piilevää $C$. acutatum -tartuntaa. Aikaisemmin on todettu valkoapilan ja eräiden muiden mansikkamailla kasvavien kasvien säilyttävän mustalaikkua vuodesta toiseen. Onkin mahdollista, että tartunta voi jäädä viljelylohkolle mansikan jälkeen leviämällä rikkakasveihin elävistä kasveista tai kasvinjätteestä ja jatkamalla niissä säilymistä edelleen. Mustalaikkua ei ole tavattu suomalaisessa taimiaineistossa, mutta se tulee varmasti edelleen mansikkaviljelmille tuontitaimien mukana, jos taimituotannossa ei huolehdita tautivapaudesta. Viljelykierto ja tehokas rikkakasvien torjunta auttavat torjumaan tautia. Norjassa $C$. acutatum on tärkein kirsikkasadon pilaaja ja sitä esiintyy myös omenalla. Tautia on havaittu omenalla myös Suomessa, samoin sitä esiintyy pihlajan ja pensasmustikan marjoissa.

Asiasanat: mansikka, kasvitaudit, säilyminen, ilmasto, isäntäkasvit 


\section{Johdanto}

Colletotrichum acutatum oli mansikalla karanteenituhooja Euroopan yhteisön kasvinterveyslainsäädännössä vuoteen 2008 asti. Se todettiin ensimmäisen kerran Suomessa mansikalta vuonna 2000 maahan tuoduissa taimissa (Parikka \& Kokkola, 2001). Taudinaiheuttajaa ei ole esiintynyt suomalaisessa mansikan taimituotannossa. C. acutatum aiheuttaa mansikalla marjojen pilaantumista, tummia laikkuja lehtiruoteihin ja rönsyihin sekä juurenniskan mätänemistä.

Taudinaiheuttajan säilymistä keinollisesti tartutetuissa mansikan lehdissä, juurakoissa ja hedelmissä tutkittiin Suomessa ensimmäisen kerran 2002-2003, jolloin kasviainesta säilytettiin talven yli ulkona maan pinnalla ja maalla peitettynä. Kokeen tuloksena havaittiin, että $C$. acutatum säilyi talven yli tartutuskykyisenä, mikä todennettiin tartuttamalla pyydyskasveina käytettyjä mansikan taimia tutkittavalla kasvinjätteellä (Parikka ym., 2006). Pitempiaikaista säilymistä tutkittiin 2002-2005, jolloin $C$. acutatum ei aiheuttanut oireita pyydyskasveihin, mutta kasveja tutkittaessa PCR tulokset olivat positiivisia (Lilja ym., 2006).

C. acutatum on moni-isäntäinen taudinaiheuttaja. Sen isäntiä ovat monet koristekasvit, sekä hedelmä- ja marjakasvit (Anon.,1997). Norjassa C. acutatum on eristetty makeakirsikalta, joka kasvoi mansikkaviljelmän vierellä, samoin taudinaiheuttaja on todettu muilla marjakasveilla ja rikkakasveilla (Stensvand ym., 2006). Se on myös tärkeä hedelmien, kuten omenan pilaaja, jota on havaittu Norjassa hedelmien lisäksi myös omenan kukkasilmuissa (Børve \& Stensvand, 2007). Berrie \& Burgess (2003) mainitsevat 35 rikkakasvilajin voivan saada tartunnan ja levittää sen edelleen mansikalle. Kuitenkin vain harvoilla lajeilla kehittyy tautioireita. Parikka \& Lemmetty (2012) totesivat, että kasvihuoneessa tehdyissä tartutuskokeissa vain hunajakukassa ja piharatamossa havaittiin tautioireita, mutta taudinaiheuttaja tartutti tutkittuja kasvilajeja ja säilyi niiden jätteessä ulkona joitakin kuukausia, enimmillään vuoden ja sen havaittiin säilyvän myös elävissä kasveissa talven yli. C. acutatum voi elää kasveilla epifyyttinä niiden pinnalla ja endofyyttinä solukoissa piilevänä tartuntana (Freeman ym., 2001; Leandro ym., 2001). Tämän vuoksi tautia on vaikea havaita ja torjua.

Tutkimuksen tavoitteena oli selvittää, kuinka kauan C. acutatum säilyy saastuneessa mansikan kasvinjätteessä erilaisissa ilmasto-oloissa Pohjoismaissa. Tavoitteena oli parantaa taudin hallintaa lisäämällä tietoa taudinaiheuttajan säilymisestä viljelypaikalla ja mahdollisesta tartunnasta muista isäntäkasveista, kuten rikkakasveista mansikkaan.

\section{Aineisto ja menetelmät}

Colletotrichum acutatum- sienen säilymistä maassa ja maan pinnalla pohjoisissa oloissa tutkittiin 2008-2012. Tutkimusta tehtiin erilaisissa ilmasto- ja lumioloissa Suomessa, Norjassa ja Tanskassa. Suomessa koepaikkoja olivat Jokioinen, Mikkeli ja Sotkamo, Norjassa Ås ja Ullensvang, Tanskassa Kööpenhamina. Suomessa kokeet alkoivat lokakuussa 2008, Norjassa ja Tanskassa syksyllä 2009.

Kokeita varten mansikan lehtiä, lehtiruoteja, rönsyjä, marjoja ja juurakoita tartutettiin sienen itiösuspensiolla kasvihuoneessa. Kasvimassaa pidettiin kosteana, jotta sieni alkaa tuottaa itiöitä. Sen jälkeen massa kuivatettiin ilmakuivaksi ja hienonnettiin. Kasviainesta pakattiin nylonverkkopusseihin ja pussit asetettiin maan pinnalle tai 7-9 $\mathrm{cm}$ syvyyteen maalla täytettyihin 7,5L muoviruukkuihin. Jokioisilla ruukut täytettiin turve-hiekkaseoksella, Mikkelissä ja Sotkamossa paikallisella kivennäismaalla. Valmiit ruukut upotettiin maahan. Lämpötilaa seurattiin maan pinnalta ja maan sisästä pussien tasolta (Elog 9004, Elcoplast Oy), maan pinnalla käytettiin myös kosteutta mittaavia loggereita (Tinytag Plus 2 TGP-4500)

Koepaikoilta tarkastettiin $C$. acutatum-sienen säilyminen poistamalla ruukuista pusseja talven jälkeen toukokuussa sekä kesän jälkeen lokakuussa. Suomessa näytteitä otettiin keväällä ja syksyllä 2009, 2010 ja 2011. Norjassa ja Tanskassa näytteenotot olivat keväällä ja syksyllä 2010 ja 2011. Åsin koealueelta saatiin näytteitä vielä keväällä 2012.

Pusseista ollut kasvinjäte kuivatettiin ja käytettiin kasvihuoneessa pyydyskasvitestiin, jossa nuorten mansikan taimien (cv Jonsok) tyvelle asetettiin tutkittavaa kasvinjätettä. Kasvihuoneessa kosteus pidettiin sumuttamalla korkealla (100\%) aluksi $24 \mathrm{~h}$ ja sen jälkeen sumutusta käytettiin viikon ajan öisin. Lämpötila viiden viikon testijakson aikana oli $26^{\circ} \mathrm{C}$. Sen jälkeen kasveista otettiin näytteet lehtiruotien tyveltä ja juurenniskasta PCR-testiin, jossa käytettiin lajispesifisiä alukkeita (Martinez- 
Culebras ym., 2003). DNA-eristyksissä oireettomista kasveista käytettiin aikaisemmin kuvattua menetelmää (Parikka \& Lemmetty, 2004).

Kesällä 2010 kerättiin koealueilta ruukuissa kasvinjätteen lähellä kasvaneista heinistä ja rikkakasveista C. acutatum-sienen esiintymistä PCR-määrityksin.

\section{Tulokset ja tulosten tarkastelu}

Pyydyskasveista tehtyjen testausten perusteella C. acutatum säilyi kaikilla koepaikoilla sekä maassa että maan pinnalla vähintään yhden talven yli. Kööpenhaminan yliopistolla olleesta kokeesta positiivisia PCR-tuloksia saatiin vain perustamista seuraavana keväänä otetuista näytteistä. Norjassa Åsin koealueella $C$. acutatum säilyi vuoden verran, mutta todennäköisesti veden kertyminen ruukkuihin tuhosi elävän sienen ja seuraavien näytteenottokertojen tulokset olivat negatiivisia. Ullensvangin koepaikalla olosuhteet olivat paremmat, eikä liika märkyys vaikuttanut taudinaiheuttajan säilymiseen. Siellä C. acutatum säilyi kahden vuoden ajan. Ilmastollisilta oloiltaan norjalaiset koepaikat eivät eroa toisistaan. Eastburn \&Gubler (1992) ovat aikaisemmin todenneet, että erityisesti maan lämpimyys ja liika kosteus edistävät sienen tuhoutumista.

Suomessa koepaikkojen välillä oli myös eroja, sillä heikoimmin sieni säilyi Mikkelin koepaikalla, alle kaksi vuotta. Syynä saattoi olla myös veden kertyminen joihinkin ruukkuihin, joista otetuissa näytteissä ei ollut enää elävää taudinaiheuttajaa. Toisaalta ruukut olivat hyvin aurinkoisella ja kuumalla paikalla ja kesällä 2010 lämpötilat maan pinnalla ja maassa nousivat tavanomaista korkeammiksi. Lumipeite kesti melko pitkään ja lämpötila lumen alla nousi kevätkaudella.

Jokioisten koepaikalla $C$. acutatum säilyi tartutuskykyisenä kahden vuoden ajan. Koepaikka oli metsän suojassa ja lämpötilojen vaihtelu oli vähäistä eikä märkyyttä ollut liikaa. Lumipeite tuli myöhään ja maa jäätyi alkutalvesta pysyen myös kylmänä keväällä. Sotkamossa lumipeite kesti pitkään ja maa ei välttämättä ehtinyt jäätyä syksyllä. Toisaalta lämpötilat koealueella eivät nousseet kovin korkeiksi maassa tai maan pinnalla. C. acutatum säilyi yli kaksi vuotta tartutuskykyisenä Sotkamon oloissa maan pinnalla. Maahan haudatussa kasviaineksessa säilymisestä ei saatu näyttöä vuoden jälkeen. Kaksi vuotta $C$. acutatum säilyi maassa vain Jokioisilla ja Ullensvangissa. Jokioisilla, Mikkelissä ja Ullensvangissa havaittiin sienen säilyvän kahden talven ja yhden kesän yli (18 kk) maan pinnalla.

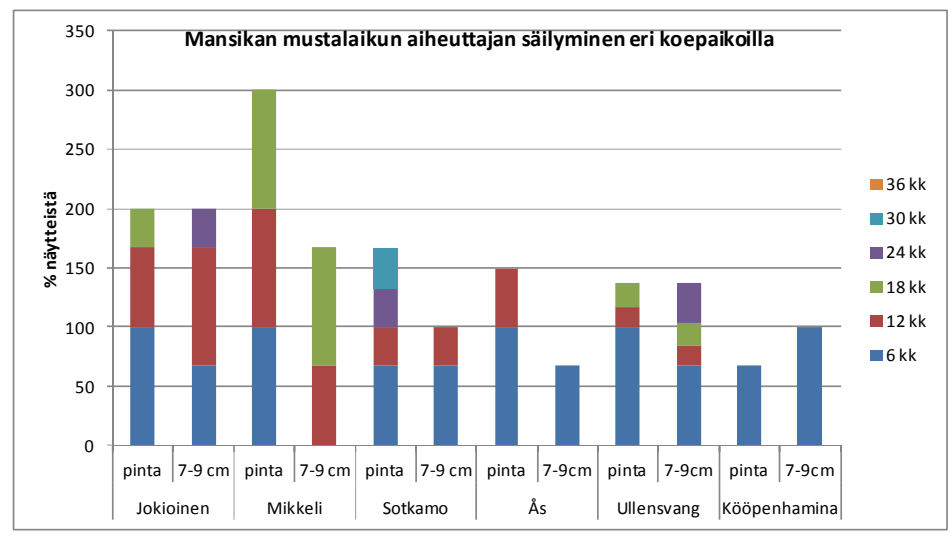

Kuva 1. Mustalaikun aiheuttajan säilyminen koepaikoilla vuosina 2008-2012. Jokioisilla, Mikkelissä ja Sotkamossa kokeet alkoivat syksyllä 2008 ja viimeiset havainnot ovat syksyltä 2011. Norjassa ja Tanskassa kokeet alkoivat syksyllä 2009.

Koealueilla ruukkuihin kasvoi nopeasti heinää ja erilaisia rikkakasveja, joista saatiin kesällä 2010 positiivisia PCR-tuloksia. C. acutatum todettiin seuraavilta lajeilta: Plantago major (Jokioinen ja Sotkamo), Stellaria media (Jokioinen ja Sotkamo), Ranunculus repens (Jokioinen), Geranium pratense (Sotkamo) ja sekalaiset rikkakasvit (Mikkeli). Kuitenkaan Mikkelissä ja Sotkamossa ruuk-kuihin kasvaneissa heinissä tai puna-apilassa ei todettu tartuntaa. Aikaisemmin on valkoapilan havaittu säilyttävän hyvin Colletotrichum-tartuntaa sekä kuolleessa kasviaineksessa että elävissä kasveissa. 
Myös Stellaria media- ja Plantago major-lajien on havaittu olevan Colletotrichum-sienen säilyttäjiä (Parikka \&Lemmetty, 2012).

Colletotrichum acutatum- lajia esiintyy luonnonvaraisen pihlajan marjoissa myös Suomessa, samoin se tartuttaa omenaa aiheuttaen varastolaikkuja.

\section{Johtopäätökset}

Yhteenvetona tuloksista voi todeta, että $C$. acutatum voi säilyä kasvinjätteessä pohjoismaiden oloissa parhaiten viileimmillä alueilla ja heikoimmin eteläisimmillä alueilla, missä kasvukausi on pitkä ja routaa ei esiinny. Pohjoisessa taudinaiheuttaja voi säilyä jopa lähes kolmen vuoden ajan, mutta säilyvän tartunnan määrä vähenee jo vuoden jälkeen. Rikkakasvit voivat kuitenkin saada tartunnan ja säilyttää sitä elävissä kasveissa tai kasvinjätteessä edelleen. Mustalaikun torjunnassa huolellinen rikkakasvien torjunta on tärkeää. Erityisesti olisi vältettävä valkoapilan esiintymistä mansikkamailla, sillä se voi säilyttää tautia hyvin. Myös viljelykierto on mustalaikun hallinnassa tärkeä, vaikka tautia ei viime vuosina olekaan esiintynyt haitallisena marjantuotannossa. Se voi kuitenkin edelleen levitä nopeasti viljelmille taimissa. Lisäksi taudinaiheuttajaa esiintyy pensasmustikan marjoissa, pihlajalla sekä omenalla myös Suomessa. Kaikkialla kasvava pihlaja on mahdollinen tartunnan lähde mansikalle, vaikka sillä esiintyvä $C$. acutatum-tyyppi ei ehkä ole yhtä aggressiivinen kuin mansikalta lähtöisin oleva.

\section{Kirjallisuus}

Anon. 1997. Colletotrichum acutatum. Quarantine Pests for Europe. Second Edition. Data sheets on quarantine pests for the European Union and for the European and Mediterranean Plant Protection Organization. p.692-697. (eds. I.M. Smith, D.G. McNamara, P.R. Scott, M. Holderness and B. Burger). University Press, Cambridge. $1425 \mathrm{p}$.

Berrie, A.M. \& Burgess, C.M. 2003. A review of research on epidemiology and control of blackspot of strawberry (Colletotrichum acutatum) with special reference to weeds as alternative hosts. Proc IOBC-WPRS Working Group 'Integrated Plant Protection In Orchards subgroup 'Soft Fruits', Dundee, Scotland 18-21 September 2001. (eds. S.C. Gordon and J.V. Cross) Bulletin-OILB-STROP 26:163-168.

Børve, J. \& Stensvand, A. 2007. Colletotrichum acutatum found on apple buds in Norway. Online. Plant Health Progress doi:10.1094/PHP-207-0522-01-RS.

Eastburn, D.M. \& Gubler, W.D. 1992. Effects of soil Moisture and temperature on the survival of Colletotrichum acutatum. Plant Disease 76:841-842.

Freeman, S., Horowitz, S. \& Sharon, A. 2001. Pathogenic and nonpathogenic lifestyles in Colletotrichum acutatum from strawberry and other plants. Phytopathology 91:986-992.

Leandro, L., Gleason, M.L, Nutter, F.W. Jr., Wegulo, S. \& Dixon, P. 2001. Germination and sporulation of Colletotrichum acutatum on symptomless strawberry leaves. Phytopathology 91:659-664.

Lilja, A., Parikka, P., Pääskynkivi, E., Hantula, J., Vainio, E., Vartiamäki, H., Lemmetty, A. \& Vestberg, M. 2006. Phytophthora cactorum and Colletotrichum acutatum: survival and detection. Agriculturae Conspectus Scientificus 71(4):121-128.

Martinez-Culebras, P.V., Querol, A., Suarez-Fernandez, M.B., Garcia-Lopez, M.D. \& Barrio, E. 2003. Phylogenetic relationships among Colletotrichum pathogens of strawberry and design of PCR primers for their identification. Journal of Phytopathology 151:135-143.

Parikka, P. \& Kokkola, M. 2001. First Report of Colletotrichum acutatum on Strawberry in Finland. Plant Disease 85:923.

Parikka, P. \& Lemmetty, A. 2004. Tracing latent infection of Colletotrichum acutatum on strawberry by PCR. European Journal of Plant Pathology 110:393-398.

Parikka, P. \& Lemmetty, A. 2012. Survival of Colletotrichum acutatum on Alternate Hosts. Acta Hort 926:645-649.

Parikka, P., Pääskynkivi, E. \& Lemmetty, A. 2006. Survival of Colletotrichum acutatum in dead plant material and soil in Finland. Acta Hort. 708:131-134.

Stensvand, A., Talgø, V., Strømeng, G.M., Aamot, H.U., Børve, J., Sletten, A. \& Klemsdal, S. 2006. Colletotrichum acutatum in Norwegian strawberry production and potential sources of inoculum in and around strawberry fields. IOBC wprs Bulletin 29(9):87-91. 